\title{
Analysis of the Center Point of Indonesia (CPI) Reclamation Policy of Makassar City in the Environmental Political Perspective
}

\author{
Suhardi \\ Alumni of the Political Science program, Faculty of Social and Political Sciences, Hasanuddin University, Student \\ of Master Program in Political Science, University of Indonesia, Indonesia \\ http://dx.doi.org/10.18415/ijmmu.v8i10.2985
}

\begin{abstract}
The purpose of this study is to analyze the impacts that arise from the CPI reclamation, viewed from the perspective of environmental politics. From an environmental perspective, the reclamation policy does not have a good impact according to its essence and purpose, it actually increases disaster risk for Makassar City, especially coastal areas, both land and sea. This research was conducted qualitatively in a case study of the CPI reclamation, by conducting in-depth interviews and field observations as well as extracting the necessary data from related sources. The CPI reclamation has attracted the attention of a number of NGOs that have formed an alliance to demand that the reclamation be stopped because it has damaged the surrounding environment and has caused economic and material harm to coastal communities. Fishermen and shellfish seekers totaling 43 heads of families who inhabit a land area of approximately 10 hectares, were evicted by the Southern Provincial Government for the construction of CPI reclamation. The sustainability of the CPI reclamation project is still reaping the pros and cons until now, especially the negative impacts that are generated are not only socio-economic problems but also have an impact on the environment. The reclamation policy actually has a negative impact on the environment, contrary to the essence of the policy itself which should bring goodness to life.
\end{abstract}

Keywords: Policy; CPI Reclamation; Environmental Politics

\section{Introduction}

Environmental politics cannot be separated from development issues. Development is always identified with progress, wealth, and prosperity which is not far from economic motives and leads to the paradigm of modernity.

Reclamation is the government's choice in development, especially to expand space in coastal areas. This phenomenon is spreading in various big cities in Indonesia such as; Jakarta Bay reclamation, Balikpapan Bay reclamation, Bali Benoa Bay reclamation, Palu Bay reclamation, Semarang Marina Beach reclamation, Surabaya Kenjer Beach reclamation, Manado Serio Beach reclamation.

The implementation of reclamation must refer to Government Regulation Number 27 of 2012 concerning Environmental Permits, Government Regulation Number 122 of 2012 concerning Reclamation in Coastal Areas and Small Islands, and Law Number 32 of 2009 concerning Environmental 
Protection and Management which states in Article 36 paragraph (1) that "Every business and/or activity that is required to have an Amdal (Environmental Impact Analysis) or Environmental Management Efforts and Environmental Monitoring Efforts (UKL-UPL) must have an environmental permit". This regulation is designed to protect the declining quality of the environment and threatens the survival of human life and other living creatures, so that serious and consistent environmental protection and management is necessary by all stakeholders (Law Number 32 of 2009 concerning Environmental Protection and Management).

The reclamation of Makassar City was carried out on Losari Beach with an area of 157.23 Ha. The positive impacts of reclamation activities include increasing the quality and economic value of coastal areas, reducing land that is considered less productive, adding areas, protecting beaches from erosion, improving aquatic habitat conditions, absorbing labor and others. Meanwhile, the negative impacts of the reclamation process on the environment include physical impacts such as changes in hydro-oceanography, sedimentation, increased water turbidity, marine pollution, increased potential for flooding and inundation in coastal areas, damage to marine habitats and their ecosystems. In addition, reclamation also has an impact on socio-economic changes such as difficulties in public access to the beach, and reduced livelihoods (Huda, 2013).

Losari beach reclamation received resistance from the community. Some community groups refused; The Save the Coastal Alliance (ASP) which consists of WALHI South Sulawesi, Blue Forest, LBH Makassar, and others. The group rejected the Losari reclamation plan and specifically highlighted the construction of the Center Point of Indonesia (CPI) area which is considered the entrance to Losari's reclamation. CPI is a mega-project initiated by the Provincial Government, but the activity is considered not to have received permission from the Central Government as regulated in the laws and regulations concerning coastal reclamation planning guidelines. Although CPI's reclamation activities are not supported by the Central Government, reclamation is still carried out by the Provincial Government by cooperating with the private sector as investors.

All regulatory obstacles can be solved by the private sector by taking various approaches through the local government to smooth out their mega-projects. This is evidenced by the hoarding carried out by the private sector based on the principle permit issued by the Makassar City Government based on the 2006 Regional Regulation on reclamation which is intended only for the Losari beach area.

As a result of the construction of the CPI reclamation, around 43 families lost their homes and livelihoods. In addition, the development of reclamation has the potential to damage coastal ecosystems and small islands around Makassar City. These changes give rise to ecosystem changes such as changes in current patterns, erosion and coastal sedimentation. This has the potential to increase the risk of flooding, and the potential for environmental disturbances in other areas (such as hill crushing or island crushing for stockpile material).

The Director of WALHI South Sulawesi, Muhammad Al Amin, said that the policy that was born through the 2015-2034 Makassar City Spatial Planning Regulation did not depart from a proper environmental analysis. The environmental impact that is given is not only in the reclamation area, but also in the areas where the fill is taken. In the case of the CPI reclamation, the hoarding of 157.23 hectares resulted from the excavation of sand in the sea of Kab. Takalar is 22,627,480 cubic meters. Apart from the sea, heap material is also obtained from the mainland in Kab. Gowa and Maros. The impact of quarrying sand and backfill results in losses to local residents' settlements and environmental damage.

The author tries to frame the dynamics of the CPI reclamation policy as a form of environmental political perspective, where the policy can have a good or bad impact on the environment around the reclamation. Issues such as damage to marine ecosystems, depletion of fish stocks in the sea, water pollution, and degradation of dredged land present real challenges for policy makers to society. 
This study is intended to analyze CPI's reclamation policy which is framed in the perspective of environmental politics. Based on the description of the background, the author is then interested in conducting research related to the Analysis of the Makassar City Center Point of Indonesia (CPI) Reclamation Policy in the Perspective of Environmental Politics.

\section{Literature Review}

\section{Environmental Political Perspective}

The study of environmental politics began in the late 1960s until the early 1970s. In the traditional view, environmental problems are still often discredited and are still seen as not part of public policy issues. This caused a reaction from some circles who care about the environment to voice how important the environment plays a role in politics. Until all policy decisions have to be made based on their potential impact on the environment.

Ideally politics will also color the environmental struggle. The relevance between the two can be seen in policy issues. What is unique about environmental politics is that it places the achievements of the political struggle by raising issues of saving the environment rather than raising other issues. This ideology believes that efforts to save the environment can be resolved by political means.

After the reclamation project has been carried out until now, the impact of the environmental damage has begun to be seen in the last two years. The rainy season that hit Makassar made various areas inundated much faster, in this case related to urban drainage. Here, it is worth worrying about the government's efforts to build building infrastructure but do not pay attention to environmental aspects.

In Dobson \& Lucardie, (1995). perspective, ecocentrism is included in the category of Critical Theory which emerged as a response to the dark part in the development of science, industrialization and modernization (Dobson \& Lucardie (1995). So this thought started as a result of worrying about the negative impacts of human actions that could affect the environment and nature.

Dobson \& Lucardie (1995) in the ecocentrism approach understands a concept known as Environmental Philosophy or environmental philosophy. In environmental philosophy, it discusses the moral relationship between humans and nature. This moral relationship between humans and nature builds ecocentrism values embodied in environmental ethics. In simple terms, environmental ethics contains values that inform how we act towards the environment and nature, whether directly, such as protesting, or holding an environmental movement or green movement, or through making environmental policies or regulations (Connelly et al., 2012).

The ecocentrism theory approach becomes a reference in this research. Basically, ecocentrism is present as a form of resistance that considers humans as the main factor in the progress of civilization, so that development related to the pattern of human life, industry, factories and all developments continues to be developed without paying attention to the surrounding ecology.

\section{Neo-Institutionalism Policy Analysis}

Policy analysis can be defined as an intellectual and practical activity aimed at creating, critically assessing and communicating knowledge about and in the policy-making process (Dunn, 2000). In policy analysis we can analyze the formation, substance and impact of certain policies, such as who benefits from the Center Point of Indonesia beach reclamation policy, who is involved in the formulation of these policies and what are the impacts on coastal communities.

Policy analysis requires a clear definition of a problem and the variables to be measured. According to Glover (1994), in many cases, a decision is made through bargaining with many parties 
(multilateral bargaining). The definition of a policy problem depends on the pattern of involvement of policy stakeholders, because they influence and are influenced by government decisions. public policy, so that the policy system is a dialectical process in which the objective and subjective dimensions of policy making cannot be separated from practice (Dunn, 2003).

In the approach of Neo-Institutionalism or New Institutionalism sees state institutions as things that can be improved towards certain goals which practically determine the steps to achieve the goals. The attention of the new institutionalism is more focused on economic analysis, monetary fiscal policy, markets and globalization rather than the issue of juridical constitution. The essence of the new Institutional was formulated by Goodin (1996) as follows:

1. Actors and groups carry out their projects within a collectively constrained context.

2. These restrictions consist of institutions, namely: a) the pattern of norms and roles that have developed in social life, and b) the behavior of those who hold that role. The role is socially defined and undergoes constant change.

3. However, these restrictions in many ways also benefit individuals or groups in pursuing their own projects.

4. This is because the factors that limit the activities of individuals and groups, also affect the formation of preferences and motivations of actors and groups.

5. These restrictions have historical roots, as a legacy of past actions and choices.

6. These restrictions create, maintain, and provide different opportunities and strengths to individuals and groups of each.

\section{Conception of Development and Reclamation}

\section{a. Development}

Development according to Rogers (Rochajat, et al: 2011: 3) is a useful change towards a social and economic system that is decided as the will of a nation. Furthermore, according to W.W Rostow (Abdul: 2004: 89) development is a process that moves in a straight line, namely from an underdeveloped society to an advanced society.

Development is essentially a process of transforming society from one situation to another which is closer to the aspired social order; In the transformation process, there are two things that need to be considered, namely continuity and change. The attraction between the two creates dynamics in the development of society.

\section{b. Reclamation}

According to Article 1 paragraph 23 of Law no. 27 of 2007 concerning Management of Coastal Areas and Small Islands, reclamation is an activity carried out by people in order to increase the benefits of land resources from an environmental and socio-economic point of view by means of backfilling, drying of land or drainage.

The substance of reclamation is to turn useless areas into potential and useful for the public. The new area is usually used for residential, industrial, business, agricultural and tourist areas. In urban planning, coastal reclamation is one of the steps for the expansion of the city.

\section{Methods}

The research approach, according to Creswell \& Creswell (2017) is a structured plan or research procedure from broad assumptions to detailed methods of data collection, analysis and interpretation. The assumption of this research is based on the interpretative paradigm or constructivism which assumes that 
every individual or actor always tries to understand the world in which they live and work (Creswell \& Creswell (2017). In other words, the researcher seeks to find the complexity of views rather than narrowing meanings into a number of categories and ideas. This approach also leads to subjective meanings interpreted by individuals based on social and theoretical negotiations.

This research was carried out in South Sulawesi, precisely in Makassar City, which is the focus area of the author's research, especially the Center Point of Indonesia (CPI) beach reclamation area in Mariso District. This research was conducted through a qualitative approach. This means that the data collected comes from interview scripts, field notes, personal documents, memo notes, and other official documents. The form of this research is a case study. This study is intended to examine clearly and in depth the impact of coastal reclamation on environmental conditions around the Makassar City CPI reclamation project which is then processed and analyzed to draw conclusions.

\section{Results and Discussion \\ Impact of Coastal Reclamation Policy on Environmental Conditions Around Makassar City Cpi Reclamation Project}

Before looking further into the reclamation of the environment around the reclamation, it is necessary to take a closer look at how the reclamation policy was then created from the initiative of the provincial government. The policy field is the main aspect of how reclamation is studied politically, as well as a crucial factor for other impacts that arise after the project is implemented. The politics of territorial control and management on all fronts without due consideration of the principle of prudence has actually increased tenurial, social and human rights conflicts and created poverty and environmental damage.

\section{CPI reclamation regulations}

The initial construction of the CPI reclamation in 2009 to 2013 was carried out by the Provincial Government of South Sulawesi using the Regional Revenue and Expenditure Budget (APBD) of South Sulawesi Province. PT. Yasmin Bumi Asri. On November 1, 2013, two South Sulawesi Governor Permits were issued, namely Number: 644/6272/Tarkim concerning Reclamation Location Permits in the Central Integrated Business Area of Indonesia in South Sulawesi Province as a Provincial Strategic Area, on behalf of PT. Yasmin Bumi Asri was then followed by a second letter Number: 644/6273/Tarkim concerning Permits for the Implementation of Reclamation in the Central Integrated Business Area of Indonesia in South Sulawesi Province (Kamal, 2017).

The Coalition of the Save the Coastal Alliance (ASP) found that the reclamation location permit, which should have been the basis for issuing a permit from the Governor, never received a recommendation from the Minister of Maritime Affairs and Fisheries. Whereas in Article 8 paragraph (1) of the Regulation of the Minister of Maritime Affairs and Fisheries Number 17 of 2013 concerning Licensing of Reclamation in Coastal Areas and Small Islands stipulates "Reclamation location permits with an area of more than 25 (twenty five) hectares must obtain a recommendation from the minister" . Meanwhile, the reclamation area stated in the disputed object administrative administrative decision is 157.23 ha (Aspan, 2017).

Issuance of Permits and signing of MoU with PT. Yasmin Bumi Asri and then with PT. Ciputra, shows how easy it is for property companies to invest in Makassar City. As Harvey argues, that entrepreneurs do not absolutely need an institutional framework to function, but without that framework they will be faced with greater risks. 
The Makassar City Regional People's Representative Council should pay more attention to the surrounding environment and consider the needs of the community or the norms that apply in society. Increased supervision carried out by interest groups and the media, while on the other hand it appears that the role of the legislature has declined as representatives of the people.

This is in accordance with Heywood (2014) view that the rise of interest groups has threatened the legislature in a number of aspects. First, the groups provide the public with an alternative representation mechanism. Such groups tend to be more effective than legislatures in raising public concerns. Second, the vulnerability of the legislature to lobbying has undermined their legitimacy. Public perception is increasing that legislators are more motivated by personal interests than the passion to serve the community.

Interest groups have shown their role as actors conducting campaigns, socializing reclamation and putting pressure on the executive and legislative bodies to stop reclamation activities. Each of these roles has been owned by each actor who acts according to the values adopted, but as stated by (Goodin,1996), the existence of these institutions has given freedom for each actor to put forward his own interests. This is certainly influenced by the motivation of the actor. Interest groups have shown their interests, namely the rejection of reclamation, while the executive and legislative institutions as well as entrepreneurs have also put forward their interests, namely wanting to keep reclamation.

Conflicts of interest among the actors are based on their respective preferences which have strong historical roots. The reclamation development does not only damage the environment, but the reclamation area is a form of the bad side of capitalism and the government which has been considered selfish. Meanwhile, the executive, legislative and business entities have historical roots that reclamation is today's development demands so that Makassar City can realize its ideals as a World City.

\section{Impact of CPI's Reclamation Policy on the Environment}

CPI's reclamation policy process has an effect on the environment around the landfill. These effects tend to have a detrimental impact on the environment and coastal communities around the reclamation area. Even before there was reclamation, environmental problems such as sedimentation and abrasion often occurred, but the presence of reclamation or landfill actually accelerated the process of environmental damage.

We need to see the essence of a policy as a whole. The reclamation policy taken by the provincial government is essentially beneficial, meaning it is for the common good. The government's initial assumption is that coastal reclamation aims to mitigate coastal areas, then sedimentation that occurs for a long time needs to be tactical by making embankments as embankments, of course with all considerations and careful environmental research. The reclamation policy is oriented to the goodness of the environment and to the lives of coastal communities, but has the policy brought goodness according to its essence?

Looking at the reclamation process which is currently ongoing, the impact of the policy began to emerge and be felt directly by the community, especially environmental issues which became the main idea of reclamation. The environment in question is the land and sea environment around the CPI reclamation area.

\section{a. Environmental Impact on Land}

For Mohammad Ramdhan Pomanto, the construction of this reclamation is part of a global policy. According to him, this policy is to anticipate the consequences of rising Earth's temperature which melts ice at the North Pole and South Pole which then makes sea water rise. If that happens, so many cities on the coast will be exhausted if not immediately mitigated. 
"When we surveyed, Makassar will experience an increase of $116 \mathrm{~cm}$ in 2050. Now the effect of the increase in water is not measured in centimeters but is measured by the effect, called the Brown Effect. The Brown Effect will only have an impact of $1 \mathrm{~cm}$, it will have an impact of 100 meters, so if it is $116 \mathrm{~cm}$ then the impact will be many kilometers, it's called the Brown Effect, that's in technical language. So with that, I designed the reclamation in Makassar, which actually does not mean reclamation, but mitigation by reclamation."

Dapat disimpulkan bahwa reklamasi pantai losari perlu dilakukan untuk restrain sea level rise in order to minimize the impact that will be caused in coastal areas, especially the coastal areas of Makassar City. The CPI reclamation will also later create another business related to social and environmental issues. As Andi Yurnita said;

"We want to make other efforts related to social and environmental issues by making a reclamation plan in front of Losari beach. First, create a new activity center outside of the existing one, then create a new green open space in the reclamation area of 157 ha, 30\% of which is Green Open Space (RTH). So, 1/3 of the CPI area is a public area, namely the Green Open Space, Mosque, Wisma Negara, Coral Center (a kind of maritime research center and maritime-related expedition center created to develop research in the South Sulawesi region) and other spaces is a private area consisting of housing, then services and hospitals."

Coastal reclamation is carried out for mitigation reasons due to rising sea levels, and another reason from the government is sedimentation. Sedimentation that occurs in the Makassar waters is caused by the deposition of mud carried by the Jeneberang river current. Based on research conducted by the Department of Marine Affairs and Fisheries in the Makassar City Coastal Zone Zoning Plan, the sediment supply from the Jeneberang river based on river discharge ranged from $238.8-1,152 \mathrm{~m} 3 / \mathrm{second}$ (annual average discharge $33.05 \mathrm{~m} 3 / \mathrm{second}$ ) with a level of mud carried 25-200 g/liter. However, after the landslide disaster of Mount Bawakaraeng, it is estimated that the sediment could reach 1.3 billion cubic meters, and it is feared that this could cause silting of Losari Beach.

Filling the sea with soil material will add a series of vulnerabilities to the coast. In this case, the threats to coastal areas are abrasion, tidal flooding, inundation floods and obstruction of drainage. This vulnerability will threaten life assets, communities, property and built infrastructure, social, cultural and political activities, as well as the environment.

Some areas that have the potential and are frequently hit by tidal flooding are Tamalate, Mariso and Tamalanrea, while areas that are often exposed to inundation are Mariso, Ujung Tanah, Wajo, Tallo, Biringkanaya and Tamalanrea sub-districts. As Muhammad Al Amin said in an interview;

"When the sea is converted or converted to land, the wave space becomes narrow, causing tidal flooding during the rainy season. Now, the volume of rain from upstream that cannot flow to the sea is what causes flooding. The peak was December 2017, massive flooding that inundated because the water did not flow into the sea."

The reclamation of the CPI coast has also hampered the function of the Jongaya canal as a flood control and water flow from Makassar City. There are three main canals that regulate the drainage distribution system for disposal, namely, the Panampu, Jongaya and Sinrijala Canals with a flow length of $40 \mathrm{~km}$ each. For tertiary canals $3,200 \mathrm{~km}$ (Rusdianto, 2015). During the rainy season, the water discharges that filled the canal did not flow smoothly but instead became a long puddle. Based on interviews with the Mariso sub-district community, Opir said;

"There is no more land for water absorption due to the reclamation development. Not only that, reclamation hinders the circulation of canal water so that it accumulates like mud and smells bad. As a result, it is easy to flood during the rainy season." 
If the volume of water decreases, sand and soil mixed with water accumulate and settle at the bottom of the canal. Gradually create a thick layer of muddy and plastic waste floats. This causes the water circulation to be hampered and the water exchange process does not occur.

Disaster risk for coastal areas that are vulnerable to tidal flooding and inundation will increase as reclamation is carried out. These areas are Tamalate, Mariso, Wajo, Ujung Tanah and Tamalanrea subdistricts. Reclamation will have the effect of disappearing or closing water catchment areas in the Tamalate area to the Jeneberang watershed, as well as causing sea level rise. As a result of hoarding, there will be a rise in sea level. This will directly result in an increased risk of coastal areas affected by tidal flooding.

\section{b. Environmental Impact on the Ocean}

CPI's reclamation activities that have been taking place in the Makassar Coastal area have had a serious impact on the ecosystem of the reclamation area and the surrounding waters. Physical reclamation is a subtidal area which is a distribution area for seagrass and coral reef ecosystems. If stockpiled, this ecosystem will cause damage. The function of the ecosystem as a nursery ground and a feeding ground will also be lost. This will have an impact on the loss of associated biota on the coast of Makassar City.

Research data and periodic monitoring of coral reefs on three small islands in Makassar City by the Marine Science Diving Club (MSDC) show that the population and quality of coral reefs has decreased dramatically. Several external factors are suspected as the cause, including the ongoing CPI reclamation project. From the three islands studied, it is seen that there has been a decline in the population or percentage of coral reef cover in the last four years.

Seagrass ecosystems have the potential to experience stress with the accumulation of sediment supplied from stockpiling activities. Seagrasses around the reclamation site, such as Lae-lae Island, which is dominated by Enhalus Acoroides, are getting more and more depressed. The impact of sediment accumulation due to CPI reclamation is not only around the reclamation site but spreads to other areas, especially to the north due to the deflection of the current direction due to the reclamation embankment.

The degradation of the three main ecosystems that make up the coast, namely coral reefs, mangroves and seagrasses, has an impact on the aquatic biota associated with these ecosystems. Ecosystem functions as feeding ground, nursery ground and protection decrease when these three ecosystems are stressed and even have the potential to be lost. Not only in the waters near the reclamation area but to other waters. Of course, aquatic biota will be disturbed in their life cycle with this condition exacerbated by disturbed water quality, accumulation of sediment that inhibits the penetration of sunlight and several other side effects.

Explanation of the impact of this reclamation, a hypothesis can be drawn that CPI's reclamation policy, which should have had a good impact, has the opposite effect. This confirms that the project which is currently in progress has a side outside the essence of the policy itself which should be beneficial in nature but actually causes harm from an environmental perspective.

\section{Community Reaction to Makassar City CPI Reclamation Project}

After the reclamation project has been carried out until now, the impact of environmental damage can be felt. The rainy season that hit Makassar City made some areas flooded much faster, in this case related to urban drainage, for which there were two direct reasons; the first is that more and more semipermanent buildings are being built, disrupting groundwater absorption, secondly, with reclamation, the flow of water that should reach the sea becomes blocked and causes the water to smell.

The government's rampant efforts to build infrastructure but do not pay attention to environmental aspects are cause for concern. In addition, the people who are members of the mass 
movement rejecting the CPI reclamation demand a just social transformation. Reclamation of course does not rely on one particular aspect, but refers to other aspects. Moreover, the CPI reclamation project later disrupted the access and livelihoods of the community, especially those who make a living in the waters. Therefore, in this section the author describes the characteristics of the coastal community of Makassar City, especially in the CPI reclamation area and their reactions to the project of the Provincial Government.

\section{Makassar City Coastal Community}

Around the Losari beach, Makassar City, there is soil growing due to the sedimentation process for decades. This growing land area is approximately 10 hectares and has mangrove vegetation. This growing land is also inhabited by fishermen and shellfish seekers as many as 43 families (KK). They have inhabited this growing ground location since the 1970s. This growing land is also a favorite location for fishermen from outside Makassar as a place to moor their boats.

One of the residents evicted from the growing land he has lived in since 1979 is Daeng Bollo. According to Daeng Bollo, the evictions carried out by the state apparatus seemed sudden. Information about the evictions was not shared with residents living in the growing land area. From the eviction, many furniture and household appliances were damaged. In addition, the loss of property residents due to evictions.

"The government seems to throw us away like trash. They demolished and burned our house and did not compensate us. I have lived in the Celebes Convention Center for six years (triple-C), there has been no attention from the government for the eviction victims until now." Daeng Bollo said when he was met in one of the corners of the triple-C that he was currently inhabiting.

Forty-three families who had been evicted finally moved to the courtyard of the Celebes Convention Center (triple-C) building which was not far from where the land grew. Until now there are seven heads of families who still survive living in the courtyard of the triple-C building.

Not only a handful of people have been forced to be evicted from their homes, since the construction of the CPI project started, people's access to the Makassar sea area has begun to be limited. Fishing boats are increasingly difficult to penetrate and enter the sea area. Shell and fish seekers are also increasingly limited in access to shallow waters in Makassar City. Some shellfish seekers have stopped looking for shellfish and are looking for other jobs.

"In the end, it is definitely the upper middle class who will benefit from the added value of the properties there. So, the reclamation actually reflects the interests of the elite, the interests of the middle class in political terms. There is no argument that can prove that it benefits the little people. Fisherman households and shellfish-seeking groups lost their livelihoods. No compensation and alternative livelihoods are prepared." said Luhur Priyanto, an academic from the University of Muhammadiyah (Unismuh) Makassar City.

This damage to coastal ecosystems reduces the catch of traditional fishermen. As a result, their economic income has decreased, especially shellfish-seeking fishermen who have lost their livelihoods. Based on an interview with Dg. Show;

"Many fishermen here have had their economic life disturbed because the catch is decreasing and the fishing area is getting farther away. Many fishermen change professions to become masons, laborers, bentors, selling drinks on the roadside to meet the needs of their families." 
Many fishermen around Losari are no longer fishing. The reduced catch of fishermen has caused them to switch professions from scavengers to builders, pedicab drivers, and some even become scavengers. Because of this condition, the coastal community rejects the CPI reclamation project in Makassar City.

\section{Reaction of Non-Governmental Organizations (NGOs) in Responding to CPI Reclamation}

Coastal communities are not alone in responding to the CPI reclamation project. Several nongovernmental organizations (NGOs) have also paid attention to this issue.

"There is one group that focuses on environmental administration issues, that is the Walhi group through ASP (Aliansi Save the Coast). This is more about environmental administration, questioning the permits. In another group, there is the Anti-Corruption Community Coalition (KMAK) which is questioning the potential for corruption in the CPI reclamation development budget."

These two major groups; The Coastal Rescue Alliance (ASP) which focuses more on administrative issues such as licensing to environmental impacts, and the Anti-Corruption Community Coalition (KMAK) which focuses on issues of corruption or misuse of reclamation funds. This group consists of the Legislative Monitoring Committee (Kopel), the Legal Aid Foundation (YLBH) of South Sulawesi and the Center for Anti-Corruption Studies Patria Artha.

In 2015, coastal communities and civil society organizations rejected the allocation of a 4,500hectare reclamation space in the 2015-2035 Makassar City Spatial Planning Ranperda. The Ranperda also specifically allocates 157.23 hectares of reclamation for the construction of CPI. The public and academics have given their views regarding Makassar's coastal reclamation in a hearing meeting with the special committee of the Makassar City DPRD. said Luhur Priyanto;

"In the end, all regulations, all permits only legitimize because they are already done. Now zoning plans are made just to legitimize. It is no longer possible to prevent it because it is already done. And unfortunately, the coastal fishermen of Makassar City have lost their livelihoods due to the construction of coastal reclamation."

Mohammad Ramdhan Pomanto conveyed a different matter in a presidential socialization seminar. A presentation made at the Grand Clarion in 2012 showed that the AMDAL reclamation will not have a negative impact on the community. However, in reality, in the process of implementation alone, many coastal communities have been evicted and lost their livelihoods. In addition, marine ecosystems are undergoing destructive changes due to CPI reclamation. This is based on an analysis conducted by ASP.

"Political decisions are very indifferent to the environment, and are very risky to environmental sustainability, especially in coastal areas."

In addition to the permits that were violated in the CPI reclamation project, another case that arose later was the direct impact on coastal communities where the community lost their right to live. In an interview with Edy Kurniawan, he said that the CPI reclamation has at least robbed a number of citizens' rights that have been and will continue to be violated, including; the right to the environment, the right to private property, the right to work, the right to a decent life, the right to education, the right to health, the right to participate in aspects of local culture and traditions, and violations of the principle of non-discrimination.

This alliance, which consists of various civil society organizations, expressly rejects the allocation of reclamation space, the commercialization of the Makassar coast for the sake of developing a 
World City, which in fact is more directed at the interests of privatizing public space for commercial purposes, and for imaging. Reclamation also has a destructive impact on coastal ecosystems and small islands around Makassar City.

The resistance efforts carried out by the two NGO groups have been carried out using various methods such as demonstrations, creative campaigns, collecting signatures on petitions against reclamation, garnering support from student organizations on campuses by conducting discussions, and organizing for coastal communities. In addition, the resistance carried out was reporting the Provincial Government to the Administrative Court and reporting reclamation cases to law enforcement, including the Corruption Eradication Commission (KPK).

Once again, the Center Point of Indonesia reclamation policy taken by the Provincial Government in collaboration with the private sector is still inviting polemics in various circles. Calculation of profit and loss, damage the environment or even beautify the coast, so that the issue of the fate of coastal communities continues to be talked about.

\section{Conclusion}

CPI's reclamation policy has had a negative impact on coastal areas, both land and sea. Currently, the vulnerability of coastal areas can be demonstrated by the decreasing area of mangrove cover in coastal areas, damage to coral reefs and levels of sea water exposed to waste. Filling the sea with soil material will add a series of vulnerabilities to the coast. In this case are abrasion, tidal flooding, inundation flooding and obstruction of drainage. In addition, this vulnerability threatens life assets, communities, property and built infrastructure, social, cultural and political activities, as well as the environment. Community reaction to the CPI reclamation project. Around the Losari beach, Makassar City, there is soil growing due to the sedimentation process for decades. This growing land area is approximately 10 hectares and has mangrove vegetation. This growing land is also inhabited by fishermen and shellfish seekers as many as 43 families (KK). They have inhabited this growing ground location since the 1970s. This growing land is also a favorite location for fishermen from outside Makassar as a place to moor their boats. As the CPI project progressed, the South Sulawesi Provincial Government on March 10, 2014 carried out the eviction of residential land residents. They are considered as squatters who occupy the location of state land. The South Sulawesi Provincial Government then made the location of this growing land part of the CPI construction reclamation project site covering an area of 157.23 hectares. In the location of this growing land, the South Sulawesi Provincial Government built the Wisma Negara building. The chaos also attracted the attention of a number of NGOs that formed an alliance to demand that reclamation be stopped because it had damaged the environment and harmed coastal communities economically and materially. Until now, there are still seven heads of families who live in a room in the Celebes Convention Center building which can be evicted from time to time from the management, while other residents choose to find another place to live on their own without any help from the government.

\section{References}

Aspan, Z. (2017). Advokasi Litigasi Kasus Reklamasi Pantai Makassar (Perspektif Undang-Undang Lingkungan Hidup). Amanna Gappa, 19-24.

Connelly, J., Smith, G., Benson, D., \& Saunders, C. (2012). Politics and the environment: from theory to practice. Routledge.

Creswell, J. W., \& Creswell, J. D. (2017). Research design: Qualitative, quantitative, and mixed methods approaches. Sage publications. 
Dobson, A., \& Lucardie, P. (Eds.). (1995). The politics of nature: Explorations in green political theory. Psychology Press.

Dunn, W. N. (2000). Analisis Kebijakan Publik Edisi Kedua. Yogyakarta: Gajah Mada University

Dunn, W. N. (2003). Pengantar analisis kebijakan publik. repository.unsimar.ac.id

Rusdianto, E. (2015). Beginilah Kondisi Drainase dan Pesisir Makassar. https://www.mongabay.co.id/2015/03/22/beginilah-kondisi-drainase-dan-pesisir-makassar. Diakses 26 Juni 2019.

Goodin, R. E. (1996). Institutions and their design. The theory of institutional design, 1(53), 9-53.

Heywood, (2014). Politik Edisi Keempat. Terj. Ahmad Lintang Lasuardi. Yogyakarta: Pustaka Pelajar.

Huda, M. C. (2013). Pengaturan Perizinan Reklamasi Pantai Terhadap Perlindungan Lingkungan Hidup. Perspektif, 18(2), 126-135.

Kamal, B. (2017). Konflik Kepentingan Perebutan Pesisir Kota Makassar dalam Pembangunan Center Point of Indonesia.The POLITICS:Jurnal Magister Ilmu Politik Universitas Hasanuddin, 3(2), 83-93.

Paulson, S., Gezon, L. L., \& Watts, M. (2003). Locating the political in political ecology: An introduction. Human organization, 62(3), 205-217.

Walhi Sulawesi Selatan (2016). Laporan Kasus Reklamasi Center Point of Indonesia (CPI) di Pesisir Kota Makassar. Walhi

Walhi Sulawesi Selatan (2017). Kasus Proyek Reklamasi Centre Point of Indonesia (CPI) Dampaknya di Pesisir Kota Makassar dan Takalar. Walhi

\section{Copyrights}

Copyright for this article is retained by the author(s), with first publication rights granted to the journal.

This is an open-access article distributed under the terms and conditions of the Creative Commons Attribution license (http://creativecommons.org/licenses/by/4.0/). 